\title{
English Education Journal
}

UNNES

http://journal.unnes.ac.id/sju/index.php/eej

\section{The Fulfillment of Felicity Conditions in Speech Acts in Winfrey's Speech Learn from Every Mistake}

\author{
Indah Yuliarti ${ }^{凶}$, Januarius Mujiyanto, Mursid Saleh
}

Universitas Negeri Semarang, Indonesia

\begin{tabular}{|c|c|}
\hline Article Info & Abstract \\
\hline $\begin{array}{l}\text { Article History: } \\
\text { Recived } 28 \text { July } 2021 \\
\text { Accepted } 3 \text { October } \\
2021 \\
\text { Published } 23 \\
\text { December } 2021\end{array}$ & $\begin{array}{l}\text { This study was about fulfilling felicity conditions in speech acts in Winfrey's } \\
\text { speech Learn from Every Mistake. This research analyzed each utterance spoken } \\
\text { by Winfrey's speech entitled Learn from Every Mistake. Each utterance is } \\
\text { categorized based on five types of speech acts. The felicity of the utterance was } \\
\text { analyzed based on Searle's felicity condition theory. This study was a qualitative } \\
\text { case study. The research object was Winfrey's speech entitled Learn from Every }\end{array}$ \\
\hline $\begin{array}{l}\text { Keywords: } \\
\text { Speech Act, Felicity } \\
\text { Conditions, Case } \\
\text { Study. }\end{array}$ & $\begin{array}{l}\text { Mistake published on YouTube on } 18^{\text {th }} \text { May } 2019 \text {. The findings showed that all } \\
\text { the utterances in five types of speech act fulfilled the felicity conditions. The } \\
\text { consideration came when the utterances were in a joke which meant that the } \\
\text { speaker did not sincerely utter the utterances. There was a note when utterances }\end{array}$ \\
\hline & $\begin{array}{l}\text { in a joke were felicitous if both the speaker and the hearers truly understood that } \\
\text { the utterance was a joke. The last conclusion in felicity condition was in the } \\
\text { essential speech act. Based on the analysis, all of the utterances in Winfrey's } \\
\text { speech entitled Learn from Every Mistake were felicitous in essential condition. } \\
\text { The research finding can be used as a reference in understanding felicity } \\
\text { conditions in the speech act. }\end{array}$ \\
\hline
\end{tabular}

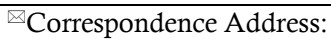

Pacasarjana UNNES J1 kelud Utara 3 Sampangan Semarang,

Indonesia

p-ISSN 2087-0108

E-mail: indahyuliarti09@gmail.com 


\section{INTRODUCTION}

People need to communicate with other people. This one is crucial because in expressing ideas, feeling, and thinking, they communicate by using spoken or written language. Spoken language is a primary way of expressing feelings and ideas. Every day, the people create utterances in asking and delivering meaning. Spoken language is also a way of asking someone to do something. It means the utterance is about the statements and the meaning and what is done by the utterance. In the pragmatic field, it is called a speech act.

In pragmatic studies, speech act has an essential role because speech act is about the intention of utterance to get the intended effect from the listener. Meanwhile, the speech act must fulfill the felicity condition. It means that utterance should be suitable for the condition when the speaker speaks utterance. The utterance should also be sincere and has a clear goal, and the speaker is willing to deliver utterance. Yule (1996) states that felicity condition is certain expected or appropriate circumstances for the performance of a speech act to be recognized as intended. Also, failed utterances are not described as false but rather as improper, unsuccessful, or, in general, infelicitous (Horn \& Ward, 2006). It means that the felicity condition in the speech act is about the appropriate condition and criteria that must be fulfilled for an utterance to achieve the purpose of the utterance itself.

There are some experts' arguments about the types of felicity conditions. Searle (1969) states that there are four conditions to make a felicitous utterance. The propositional condition is about the circumstances in which the speaker speaks the utterance. Preparatory condition is about the prerequisite of the speaker to speak the utterance. Then, the Sincerity condition is about specifying what will be achieved if the utterance is sincerely uttered. The last is essential condition. The essential condition is about the intention of utterance.

In transferring meaning by using spoken and written languages, we have a specific goal of uttering an utterance. Some experts classify speech acts in some classifications. Yule (1996) divided speech acts into five classifications, declarative, representative, expressive, directive, and commissive. According to Cruse (2000), declarative is said to change reality. The world is in some way no longer the same after they have been said. The representative act is about producing utterances in expressing speakers' believes. The expressive act is about producing utterances in expressing the speaker's feelings. Yule (1996) states that expressive is a kind of speech act that states what the speaker feels. A directive act is about asking someone to do something by using utterances. Yule (1996) states that the directive act is a speech act that the speaker uses to get someone else to do something. A commissive act is about producing utterance to express a future action. Cruse (2000) states that commissives commit the speaker to some future action. It can be in promise, vow, offer, undertake, contract, threaten.

There are some researchers who conducted study in some types of speech act. (e.g. Ulum, Sutopo \& Warsono, 2018; Mubais \& Shofwan, 2018; Shofwan \& Mujiyanto, 2018; Kohar, Bharati \& Rukmini, 2018; Ad-darraji, Foo, Ismail \& Abdulah, 2012; Wijana, 2021; Karyono, 2015; Altikriti, 2016; Al-Bantany, 2013; Nourzad \& Jabbari (2015). In the commissive speech act, Kohar, Bharati, and Rukmini (2018) and Ulum, Sutopo, and Warsono (2018) had researched this type of speech act. Ulum, Sutopo, and Warsono (2018) conducted a research commissive speech act in Trump's Speech. They found that that there were six types of commissive speech acts used by Trump. Kohar, Bharati, and Rukmini (2018) also researched the commissive speech act on the Third Presidential Debate in the United States Presidential Election 2016. They found that the importance of commissive speech acts realized in the debate is to convince the audiences based on the candidates' ideas, vision, and mission and their works ahead after one of the two candidates wins the presidential election.

Other researchers also focused on the five types of speech act especially in a classroom setting in teacher and students talk (e.g. Basra \& 
Thoyyibah, 2017; Swandewi, Ramendra \& Juniarta, 2017; Kazemi and Zamani, 2018). Swandewi, Ramendra, and Juniarta (2017) found that the most frequent speech act used by the teachers is the directive speech act that occurred when the teachers tried to give questions, request something, give a command, interrupt, invite, prohibit, motivate, give suggestion and remind. This kind of speech act presented utterances about 133 utterances with a percentage of about $62 \%$.

Some researchers also conducted research focused on the felicity condition in speech act (e.g. Al-Husseini \& A-Shaibani; 2016; Hadiati, 2019; Adnyasuari, 2017; Ogborn, 2020; Toumi, 2010). Hadiati (2019) conducted research focused on the felicity conditions in Banyumasan daily conversation in some types of speech act, directive, declarative, expressive, representative, and commisive. The finding of the research showed that felicity conditions of Banyumasan are realized into representative, directives, commisives, expressive, and declarations. Toumi (2010) researched students' awareness of felicity conditions and their attitudes towards applying felicitous speech acts. The results reveal that majority of the students become aware of felicity conditions-most of the previous studies researched two or more people's communication.

Based on the some previous researches above, the researchers were interested in researching felicity conditions in a speech in which is the speaker was dominant than the hearer. This study will help to understand felicity conditions in the speech act, especially the felicity conditions of a speech. This study also will have a contribution in developing English language teaching specially in producing meaningful utterance and spoken in appropriate conditions.

\section{METHODS}

This research used a qualitative case study research design. This study investigated the fulfillment of felicity conditions in speech acts in Winfrey's speech entitled Learn from Every Mistake. The fulfillment was in four rules in making the felicitous utterance. The four felicity conditions were propositional content, preparatory conditions, sincerity conditions, and essential conditions in five classifications of speech acts: declarative, representative, expressive, directive, and commissive.

The research object was Winfrey's speech entitled Learn from Every Mistake published on YouTube on 18th May 2019. It contained four felicity conditions in speech act, namely propositional content, preparatory conditions, sincerity conditions, and essential conditions. After obtaining the data, the data analysis was done through some steps. The first step was transcribing the video during the speech of Oprah Winfrey entitled Learn from Every Mistake. The second step was categorizing the fulfillment in five classifications of the speech act. Third, the five categories of speech acts were then analyzed based on the four felicity conditions. Afterward, analyze the finding and interpret the data. The last step was concluding.

\section{RESULTS AND DISCUSSION}

Conducting the study was to find out the fulfillment of felicity conditions in Winfrey's speech entitled Learn from Every Mistake. The writer was interested in choosing this topic because almost everyone knows that Oprah Winfrey is a top-rated talk show host, television producer, actress, author, and philanthropist. She is a very talented host who always makes her talk show more interested. The researchers were interested in conducting a study focused on making all of her utterances felicitous. So, the researchers downloaded one video from Youtube. Transcribing the video made it easier to categorize based on the five types of speech acts and analyze felicity conditions in every utterance.

\section{The Appropriateness of Preparatory Condition in Five Types of Speech Acts in Winfrey's Speech Learn from Every Mistake}

When the speaker produced the utterance, the first consideration is about the speaker's belief about the utterance that will be uttered. Belief means that he or she has fulfilled prerequisites before the utterance is spoken or in a simple 
word; the preparatory condition is about the reason for an utterance spoken by the speaker. For example, when someone gives a question, the speaker does not know the answer, and the hearer is willing to answer the question. Most of the researchers who researched felicity conditions focused on the speaker's authority and the ability to produce an utterance. It will be confusing if it is limited in those fulfillment indicators in preparatory conditions. Here, the researchers found a different finding, but it was still in the context of preparatory conditions.

The analysis found that all the five types of speech act fulfilled the preparatory conditions. Preparatory conditions were not only about the ability of the speaker to create utterances and authority of the speaker over the hearer but also in predicting the ability and predicting the hearer's willingness about what the speaker intended in her utterances. Hankemans (2014) found a similar result. They conducted a study about speech act theory. An argumentation study also found that the preparatory condition was also about the speaker's belief about the action as mentioned in the utterance. Talking about the authority of the speaker over the hearer, the speaker had fulfilled these terms. President Faust directly asked the speaker to give a speech in front of Harvard graduates, so legally, the speaker had the authority to speak in front of Harvard graduates. The ability to create an utterance, Oprah Winfrey as a speaker in this speech was well known as a great host of a T.V. program. So, she could create meaningful utterances.

In directive speech act mostly was in the form of advice from the speaker to the hearer. It happened because of the authority of the speaker to give a speech in the Harvard commencement day 2013. She tried to give some advice by telling her personality experiences during her debut in T.V. programs and after she was on television for so many years. Here is the example of analysis in the directive act in preparatory condition, as shown in Table 1.
Table1. Preparatory Condition in directive act

\begin{tabular}{|c|c|c|}
\hline \multirow[t]{2}{*}{ UTTERANCE } & \multicolumn{2}{|c|}{ FELICITY } \\
\hline & YES & $\mathrm{NO}$ \\
\hline Give yourself time to mourn & $\sqrt{ }$ & \\
\hline what you think you may have & & \\
\hline lost, but then here is the key, & & \\
\hline Learn from Every Mistake & & \\
\hline because every experience, & & \\
\hline encounter, and particularly & & \\
\hline your mistakes are there to & & \\
\hline teach you and force you into & & \\
\hline being more who you are. & & \\
\hline
\end{tabular}

Preparatory condition: $\mathrm{S}$ has the authority to give a command; $\mathrm{H}$ is willing to do what $\mathrm{S}$ said.

Propositional Content: When the speaker spoke the utterance, $\mathrm{S}$ said that one day $\mathrm{H}$ would have the worst period in their life. S advises $\mathrm{H}$ about what they have to do when that moment comes.

Sincerity Condition: $\mathrm{S}$ as a speaker in the speech, is sincere in giving her advice when the worst period of life comes.

Essential Condition: This utterance is count as advice from $\mathrm{S}$ to $\mathrm{H}$.

As shown in Table 1, in preparatory condition as a prerequisite of a spoken utterance, the speaker fulfilled preparatory condition about her authority to speak utterance and the speaker's prediction about the hearer's willingness to receive and do her advice. Utterance stated in the utterance in Table 1, the command was not in the form of the command, which had to be done directly after the speaker uttered her utterance but as advice for the future life of the hearer. So the preparatory condition was not only about the speaker's authority but also the speaker's belief that the hearer had a willingness to do what the speaker said.

\section{The Appropriateness of Propositional Content Condition in Five Types of Speech Acts in Winfrey's Speech Learn from Every Mistake}

The propositional content was about the appropriateness of circumstances when the speaker spoke the utterance. Circumstances meant that the speaker spoke the utterance 
inappropriate time, place, and conditions. For example, a judgment will be felicitous if a judge speaks it in a courtroom, not in the road or other places. The researchers found that all the utterances were felicitous in each type of speech acts because they spoke at an appropriate place on the commencement day of Harvard 2013, and the speaker chose an appropriate theme and the content of speech to motivate the hearers who started a new step of their life after graduating from Harvard University.

The researchers considered to decide whether an utterance fulfilled propositional content or not besides considering the circumstances related to time and place of the spoken utterance. The consideration of preparational content was about the appropriate time and place and the propositional content of utterances that were developed based on the previous utterance. In simple words, a propositional content of utterances can be seen from the context of utterance. For more detailed findings, the researchers would explain the finding in propositional content based on five types of speech acts.

Some sources mainly explained that propositional content in directive speech act was intended on the future action of the hearer. Referrings to those sources, all the utterances in the directive speech act in Winfrey's speech were felicitous because the utterances in directive speech act on this speech mainly for the future action of the hearer. But the researchers found that the propositional content of an utterance also could be seen from the context in specifying the kind of meaning expressed by the propositional part of the utterance. The example of finding propositional content for the directive speech act is illustrated in Table 2.

Table 2. Propositional Content Condition in Directive Act.

\begin{tabular}{ll}
\hline UTTERANCE & FELICITY \\
\cline { 2 - 2 } & YES NO \\
\hline Give yourself time to mourn \\
what you think you may have & $\sqrt{ }$ \\
lost, but then here's the key, \\
Learn from Every Mistake
\end{tabular}

\section{because every experience, encounter, and particularly your mistakes are there to teach you and force you into being more who you are.}

Preparatory condition: $\mathrm{S}$ has the authority to give a command; $\mathrm{H}$ is willing to do what $\mathrm{S}$ said.

Propositional Content: When the speaker spoke the utterance, $\mathrm{S}$ said that one day $\mathrm{H}$ would have the worst period in their life. S advises $\mathrm{H}$ about what they have to do when that moment comes.

Sincerity Condition: $\mathrm{S}$ as a speaker in the speech, is sincere in giving her advice when the worst period of life comes.

Essential Condition: This utterance is count as advice from $\mathrm{S}$ to $\mathrm{H}$.

Based on Table 2, the utterance was felicitous if referred to some sources that propositional content in directive speech act was about the future action of the hearers to do what the speaker said in her utterance. Here, the researchers found that the propositional content of the utterance was not only about the future action of the hearers but also could be seen in the context of the utterance itself. As mentioned in Johnson (2020), Hadiati (2019), and Adnyasuari (2016) the propositional content condition was about the contexts and circumstances when the utterance was spoken. An utterance would be infelicitous if it were spoken in other places and other situations. Based on the context, the speaker had said in a previous utterance that the hearers would have the worst period in their life one day. The speaker advises the hearers about what they have to do when that moment comes by producing this utterance. Based on the context and circumstances of the utterance, all of the directive speech acts in Winfrey's speech entitled Learn from Every Mistake were felicitous.

\section{The Appropriateness of Sincerity Condition in Five Types of Speech Acts in Winfrey's Speech Learn from Every Mistake}

Sincerity condition was about the psychological aspect of the speaker when she was 
speaking an utterance. The psychological here meant that the speaker, whether sincere or not when she was speaking an utterance. Analyzing sincerity conditions was another challenge because only the speaker knew whether she was sincere or not. When reading some references, most of the sources stated that sincerity meant that the speaker was not like an actor. It meant that if the speaker spoke the utterance in the actual context of communication and spoken without any pretense, it meant that the utterance was felicitous in terms of sincerity condition.

The finding showed that some of the utterances were in the form of a joke. The joke here meant that the speaker was not serious in her utterances. So, whether the utterance felicitous or not? Because Some researchers, for example, Muntiningsih (2013) and Rohmah (2013), stated that the utterance would be felicitous if uttered sincerely by the speaker and not in a joke. Then the writer decided that the joke was infelicitous in the sincerity condition was read in a transcript. Because when the readers read the transcript, they did not know that the utterances were a joke, and there was no sincerity condition when the speaker spoke the utterances because some of the utterances were known as a joke based on the intonation and expression of the speaker.

Nevertheless, the joke might be felicitous if the speaker intended the utterance for a joke. The hearer also understood that the utterance was a joke and in the actual context of speech or not based on reading the transcript. The example is in Table 3 .

Table 3. Sincerity Condition for Directive Act

\begin{tabular}{l}
\hline UTTERANCE \\
\cline { 2 - 2 } FELICITY \\
\cline { 2 - 2 } I wanted to have you look \\
under your seats, and there \\
would be free master and \\
doctor degrees, but I see \\
you got that covered \\
already.
\end{tabular}

Preparatory condition: S has the authority to speak the utterance; $\mathrm{H}$ can do the action.

Propositional Content: Based on the circumstances when the speaker spoke the utterance, $\mathrm{S}$ state that she will give something special for $\mathrm{H}$ in her speech, one of them is by giving master's and doctorate degrees, but $\mathrm{H}$ already has the degrees. $\mathrm{H}$ is the master and doctorate degrees of Harvard.

Sincerity condition: This utterance is not sincerely uttered by S.

Essential Condition: This utterance is an attempt of $\mathrm{H}$ to do what $\mathrm{S}$ said.

The researchers found that the utterance in Table 3 was felicitous if the speaker intended to make a joke and did not intend to ask the hearer to look under their seat. The hearer received the meaning of utterance as a joke also. It would be infelicitous if the reader read the transcript and did not see the expression and intonation when the speaker uttered her utterance. The reader would interpret that the speaker was not sincere in her utterance.

Another example in the fulfillment of sincerity condition was in the declarative speech act. Oprah Winfrey as the speaker in this speech, was sincere in each utterance in the declarative speech act. Because the declarative speech act was about her experience in changing the condition and the mindset of the viewers by uttering her utterance, the speaker might be sincere that the hearer would also change their mindset to help other people in need after listening to her utterance as advice for them. The speaker was also sincere in uttering advice for the hearer. The example of finding in analyzing sincerity condition for declarative speech act is illustrated in Table 4.

Table 4. Sincerity Condition for Declarative Act

\begin{tabular}{ll}
\hline UTTERANCE & FELICITY \\
\cline { 2 - 2 } So I asked for our viewers to & $\sqrt{ }$ \\
take up their change \\
collection, and in one month, \\
just from pennies and nickels \\
and dimes, we raised more \\
than three million dollars that \\
we used to send one student \\
from every state in the United \\
States to college.
\end{tabular}


Preparatory condition: S can persuade the viewers to do what she said.

Propositional Content: In this utterance based on the context, S told a story about the little girl who had decided to collect pocket change to help other people in need. By producing this utterance, $\mathrm{S}$ wants the viewers to do the same thing.

Sincerity condition: $\mathrm{S}$ wants that viewers did what she said to take up their change collection.

Essential Condition: This utterance creates a new condition of viewers' unwillingness to take up their change collection.

Based on the finding shown in Table 4, the speaker was heartfelt about her utterance. It could be seen from the speaker's effort in changing the mindset and willingness of the hearers by telling her previous experience, which was able to change the mindset of her viewer's willingness. By producing utterances as mentioned in Table 4, the speaker was heartfelt in producing this utterance to make the hearers change their mindset and willingness to help other people by doing a little thing together.

The Appropriateness of Essential Condition in Five Types of Speech Acts in Winfrey's Speech Learn from Every Mistake

The essential condition meant the intention of the speaker by performing an utterance. In other words, the essential condition was about what the utterance had to do in its intention. For example, in thanking expression as a part of an expressive act, by expressing thanking, the speaker intended the utterance for giving appreciation or gratitude for the previous action and stimuli of the hearer or other people, which resulted from the feeling and benefit for the speaker. In simple words, essential was about a goal of the spoken utterance. The detailed explanation would be explained in the following explanation based on the essential condition in five types of speech acts.

The researchers found that all of the utterances in five types of speech acts were felicitous. In the expressive act, the researchers also found that all of the utterances were felicitous in fulfilling the essential condition. Essential condition in an expressive act meant that the speaker intended to produce the utterance as a result of previous action or stimuli from the hearer or other people and circumstances that affected the speaker. The example of finding in analyzing essential conditions in the expressive act is shown in Table 5 .

Table 5. Essential Condition in Expressive Act.

\begin{tabular}{ll}
\hline UTTERANCE & FELICITY \\
\cline { 2 - 2 } & YES NO \\
\hline I was blessed with a platform that, & $\sqrt{ }$ \\
at its height, reached nearly & \\
20,000,000 viewers a day. &
\end{tabular}

Preparatory condition: $\mathrm{S}$ believes that achieving 20.000.000 viewers a day is a pride.

Propositional Content: In the past, $\mathrm{S}$ began her T.V. program in analog compared to a recent era with various media in online and offline and also technology. Now, $\mathrm{H}$ can see the achievement of her T.V. program.

Sincerity condition: $\mathrm{S}$ is sincerely proud of her T.V. program.

Essential Condition: This utterance is an expression of pride in the achievement of her T.V. program.

Based on Table 5, the utterance was felicitous in essential condition. By producing the utterance in Table 5, essentially, the speaker intended to show her pride in the achievement of her T.V. program to the hearers. Based on the context of the utterance, as an expression of pride because of her debut in the T.V. program, she was in an analog world, and there were so many obstacles included said as a flop T.V. program in the USA today newspaper. By producing this utterance, the speaker intended on proud expression in her achievement and her ability to pass those obstacles. The speaker was also optimistic that the hearer was able to do something better. 
The Relation Between Four Felicity Conditions and the Felicity of the Speech

After analyzing the felicity condition of the speech by Winfrey entitled Learn from Every Mistake, then the researcher found that there was a relationship when an utterance was not felicitous in one of the felicity conditions. It would influence the felicity of an utterance. It was supported in the study conducted by Al-Husseini and Shaibani (2016), who stated that the contract of marriage should be performed with the intention of the couple to commit themselves to perform the marriage contract, and this corresponds with the sincerity and essential conditions of Austin's (1962) and Searle's (1969) F.C.s. It was reasonable because when an utterance, for example, is promising, if promising was felicitous in preparatory condition, the speaker was sincere that she/he had the willingness to do an action as mentioned in the utterance. The utterance was also counted as an attempt of the speaker to make the hearer believe about the speaker's future actions. However, in propositional content, the circumstances were not appropriate. For example, a father who promised to buy her son a new car on his 18th birthday, but the promise was spoken when his son was already 20 years old; the promise was infelicitous.

Another example was a judge who gave a judgment on the road, not in a courtroom. The judgment was also infelicitous. The judgment was also infelicitous is spoken by the person who had no authority to give a judgment. The utterance was also infelicitous because the preparatory condition was not appropriate.

The analysis found that all utterances were felicitous in preparatory condition, propositional content condition, and essential condition. There were only some utterances that were not felicitous in sincerity conditions. However, the infelicitous utterances in sincerity condition need a note because the utterance was a joke. A joke was either the speaker was not sincere about her utterance, or the speaker was sincere that she made a joke. So, the researchers categorized the utterance as infelicitous if the speech was read in a transcript and felicitous if the speaker and hearers understood that the utterance was in a joke. An example of a joke is presented in Table 6.

Table 6. A joke as infelicitous Sincerity Condition in Representative Act.

\begin{tabular}{|c|c|c|}
\hline \multirow{2}{*}{ UTTERANCE } & \multicolumn{2}{|c|}{ FELICITY } \\
\hline & YES & $\mathrm{NO}$ \\
\hline $\begin{array}{l}\text { It was either that or a bag of } \\
\text { Oreos. So I chose the shower. }\end{array}$ & & $\sqrt{ }$ \\
\hline
\end{tabular}

Preparatory Condition: President Faust called her by phone.

Propositional Content: Because President Faust called her to speak in front of Harvard graduates and she feels as stress as when USA today write the deadline about OWN, S decided to go to the shower, so $\mathrm{S}$ has produced this utterance but assumed that the choice is not both a bag of Oreos and go to the shower.

Sincerity Condition: $\mathrm{S}$ does not sincerely go to shower after President Faust called.

Essential Condition: Count as the response of $\mathrm{S}$ when President Faust called her by phone.

The writer decided that the joke was infelicitous in the sincerity condition that was read in a transcript. Because, when the reader was not as the hearer of the speech, they did not know that the utterances were a joke. There was no sincerity condition when the speaker spoke the utterances because some of the utterances were known as a joke based on the intonation and expression of the speaker. However, the joke might be felicitous if the speaker intended the utterance for a joke. The hearer also understood that the utterance was a joke and in the actual context of speech or not based on reading the transcript.

\section{CONCLUSIONS}

After analyzing data and discussing the findings, the researchers draw some conclusions. The utterances used in Winfrey's speech entitled Learn from Every Mistake mostly were in the representative speech act. It was reasonable because the speech was one-way interaction that 
was intended to explain the phenomenon based on the speaker's point of view with a limitless response from the hearers. The expressive speech act was the second dominant speech, followed by the commissive, directive, and declarative speech acts. The analysis found that all the utterances in directive, declarative, expressive, commissive, and representative speech act fulfilled the preparatory condition, propositional content condition, sincerity condition, and essential condition. The consideration came when the utterances were in a joke. It meant that the speaker did not sincerely utter the utterances. But there was a note the utterances in a joke were felicitous that both the speaker and the hearers were truly understood that the utterance was a joke. In Winfrey's speech, the hearers understood that a joke by Winfrey was accepted as a joke, proven by the laugh response of the hearers.

\section{REFERENCES}

Ad-darraji, H. H., Foo, C. V. T., Ismail, S. A. M., \& Abdulah, E. S. (2012). Offering as a comissive and directive speech act: Consequence for cross-cultural communication. International Journal of Scientific and Research Publications, 2(3), 16.

Adnyasuari, D.P.P. (2019). Felicity condition of women's illocutions in the novel Stand by $M e$, Letters and Culture Udayana University, 3(1), 1-8.

Al-Bantany, N. F. (2013). The use of commissive speech act and its politeness implication: A case study of Banten gubernatorial candidate debate. Passage, 1(2), 21-34.

Al-Husseini, H \& Al-Shaibani, G.K.S (2016). A cross-cultural and pragmatic study of felicity conditions in the same-sex marriage discourse. Research Gate, 4(1), 5872 .

Altikriti, S. F (2016). Persuasive speech acts in Barack Obama's inaugural speeches $(2009,2013)$ and the last state of the union address (2016). International Journal of Linguistics, 8(2), 47.
Austin, J.L. (1962). How to do things with words. Oxford University Press.

Basra, S. M. \& Thoyyibah, L. (2017). A speech act analysis of teacher talk in an EFL classroom. International Journal of Education, 10(1), 73.

Cruse. A. (2000). Meaning in language. Oxford University Press.

Hadiati. C. (2019). Felicity conditions of the speech acts in Banyumasan daily conversation. Theory and Practice in Language Studies, 9(6):700.

Henkemans, A. F. S. (2014). Speech act theory and the study of argumentation. Studies in Logic, Grammar, and Rhetoric, 36(49), 41-58.

Horn, L.R. \& Ward.G. (2006). The handbook of pragmatics. Blackwell.

Johnson, C. R. (2020). Mansplaining and Illocutionary Force. Feminist Philosophy Quarterly, 6(4), 1-21.

Karyono, J. (2015). Speech act of promising used by pacitan vocational English teacher.

Kazemi, F. \& Zamani, M. (2018). Investigating speech acts in Barefoot (by Zaharia Stancu). International Journal on Studies in English Language and Literature, 6(6), 30-34.

Kohar, H. A., Bharati, D. A. L., \& Rukmini, D. (2018). The existence and responses of commissive speech act on the third presidential debate in the United States presidential election 2016. English Education Journal, 8(2), 265-271.

Mubais, A. \& Sofwan, A. (2018). Existences of promising speech act by students of English as a foreign language of Semarang state university. English Education Journal, 8(1), 27-34.

Muntiningsih, R. (2013). Indirect speech act in Judy Christenberry's novel the cowboy's secret son: A pragmatic analysis. Journal of English Language and Learning, 1(1) ISSN 2354-7340.

Nourzad, L. \& Jabbari, M. J. (2015). A crosslinguistic analysis of English-Persian commissives and directives in Mice and Men. International Journal of English and Education, 4(1), 61-73. 
Ogborn, M. (2020). Uttering geographies: Speech acts, felicity conditions, and modes of existence. SAGE Progress in Human Geography. 44(6) 1124-1140.

Rohmah, A.M. (2013). Promise categories in some American drama movies. Lexicon, 2(1), 95-104.

Searle, J.R. (1969). Speech act: an essay in the philosophy of language. Cambridge: Cambridge University Press.

Shofwan, M. I. \& Mujiyanto, J. (2018). Existence of speech acts of suggestion by EFL learners of Universitas Negeri Semarang. English Education Journal, 8(30), 87-95.

Swandewi, I. A. N. A., Ramendra, D.P., \& Juniarta, P. A. K. (2017). An analysis of speech acts used by English teachers in classroom teaching and learning process. Jurnal Pendidikan Bahasa Inggris Undiksha, $5(2)$.

Toumi, I. (2010). Students' awareness of felicity conditions and their attitudes towards the application of felicitous speech acts. Constantine University.

Ulum, M., Sutopo, D., \& Warsono. (2018). A Comparison between trump's and Clinton's commissive speech act in America's presidential campaign speech. English Education Journal, 8(2), 221-228.

Wijana, I. (2021). On Speech Acts. Journal of Pragmatics Research, 3(1).

Yule. G. (1996). Pragmatics. Oxford University Press. 